University of Montana

ScholarWorks at University of Montana

\title{
Prairie Wetland Complexes as Landscape Functional Units in a Changing Climate
}

\author{
Carter W. Johnson \\ Brett Werner \\ Glenn R. Guntenspergen \\ Richard A. Voldseth \\ Bruce Millett \\ See next page for additional authors
}

Follow this and additional works at: https://scholarworks.umt.edu/wildbio_pubs

Part of the Life Sciences Commons

Let us know how access to this document benefits you.

\author{
Recommended Citation \\ Johnson, Carter W.; Werner, Brett; Guntenspergen, Glenn R.; Voldseth, Richard A.; Millett, Bruce; Naugle, \\ David E.; Tulbure, Mirela; Carroll, Rosemary W. H.; Tracy, John; and Olawsky, Craig, "Prairie Wetland \\ Complexes as Landscape Functional Units in a Changing Climate" (2010). Wildlife Biology Faculty \\ Publications. 47. \\ https://scholarworks.umt.edu/wildbio_pubs/47
}

This Article is brought to you for free and open access by the Wildlife Biology at ScholarWorks at University of Montana. It has been accepted for inclusion in Wildlife Biology Faculty Publications by an authorized administrator of ScholarWorks at University of Montana. For more information, please contact scholarworks@mso.umt.edu. 


\section{Authors}

Carter W. Johnson, Brett Werner, Glenn R. Guntenspergen, Richard A. Voldseth, Bruce Millett, David E. Naugle, Mirela Tulbure, Rosemary W. H. Carroll, John Tracy, and Craig Olawsky 


\title{
Prairie Wetland Complexes as Landscape Functional Units in a Changing Climate
}

\author{
W. CARTER JOHNSON, BRETT WERNER, GLENN R. GUNTENSPERGEN, RICHARD A.VOLDSETH, BRUCE MILLETT, \\ DAVID E. NAUGLE, MIRELA TULBURE, ROSEMARY W. H. CARROLL, JOHN TRACY, AND CRAIG OLAWSKY
}

\begin{abstract}
The wetland complex is the functional ecological unit of the prairie pothole region (PPR) of central North America. Diverse complexes of wetlands contribute high spatial and temporal environmental heterogeneity, productivity, and biodiversity to these glaciated prairie landscapes. Climatewarming simulations using the new model WETLANDSCAPE (WLS) project major reductions in water volume, shortening of hydroperiods, and less-dynamic vegetation for prairie wetland complexes. The WLS model portrays the future PPR as a much less resilient ecosystem: The western $P P R$ will be too dry and the eastern PPR will have too few functional wetlands and nesting habitat to support historic levels of waterfowl and other wetland-dependent species. Maintaining ecosystem goods and services at current levels in a warmer climate will be a major challenge for the conservation community.
\end{abstract}

Keywords: prairie pothole wetlands, hydrology, numeric models, climate change, waterfowl

$\mathbf{F}$ reshwater wetlands worldwide are projected to be particularly vulnerable to climate change (Kundzewicz et al. 2007). Their shallow depths and rapid evaporation rates contribute most to this vulnerability. In North America, wetlands in dry climates, such as playas and prairie potholes, have especially labile surface water-most dries up seasonally in all but the wettest years. In the future, a warmer climate without compensatory increases in precipitation is expected to significantly degrade and reduce wetland areas, affecting their ability to provide ecosystem goods and services worldwide (MEA 2005).

Climate-change analyses for prairie pothole wetlands have focused on the semipermanent class-wetlands that hold water throughout most years and have more complex vegetation zonation and dynamics (Poiani and Johnson 1991, Poiani et al. 1996, Carroll et al. 2005, Johnson et al. 2005). Yet the large majority of the 5 million to 8 million wetland basins embedded in the glaciated landscapes of the prairie pothole region (PPR) in central North America (figure 1) are of the temporary and seasonal classes. Temporary wetlands generally occur as small, shallow basins that maintain surface water for only one to two months, whereas seasonal wetlands are generally larger and deeper, holding water longer (two to three months; Stewart and Kantrud 1978).
Wetland clusters of these diverse permanence types comprise a wetland complex (Weller 1988). Members of the complex, even if distant from each other, are often hydrologically connected by surface or groundwater (Winter and Rosenberry 1995, Murkin et al. 2000). Organisms move among members of the wetland complex seeking food, water, and cover (Naugle et al. 2001).

Wetland ecologists have recognized the contribution of the PPR wetland complex to ecosystem goods and services at the landscape scale (Brown and Dinsmore 1986, Fairbairn and Dinsmore 2001, Swanson et al. 2003). There are five key wetland functions that provide important services: flood abatement, water quality improvement, biodiversity enhancement, carbon management, and aquifer recharge (Gleason et al. 2008), although support for wildlife habitat and the sustainability of waterfowl and other water-dependent populations have received the most attention.

Yet little research has examined how climate change may alter prairie wetland complexes. Temporary and seasonal wetlands promote biological activity in the early spring because their dry basins recharge with snowmelt runoff when nearby semipermanent wetlands, which carry over water in most winters as thick ice, are still thawing. Swanson and colleagues (1985) reported that the availability and 


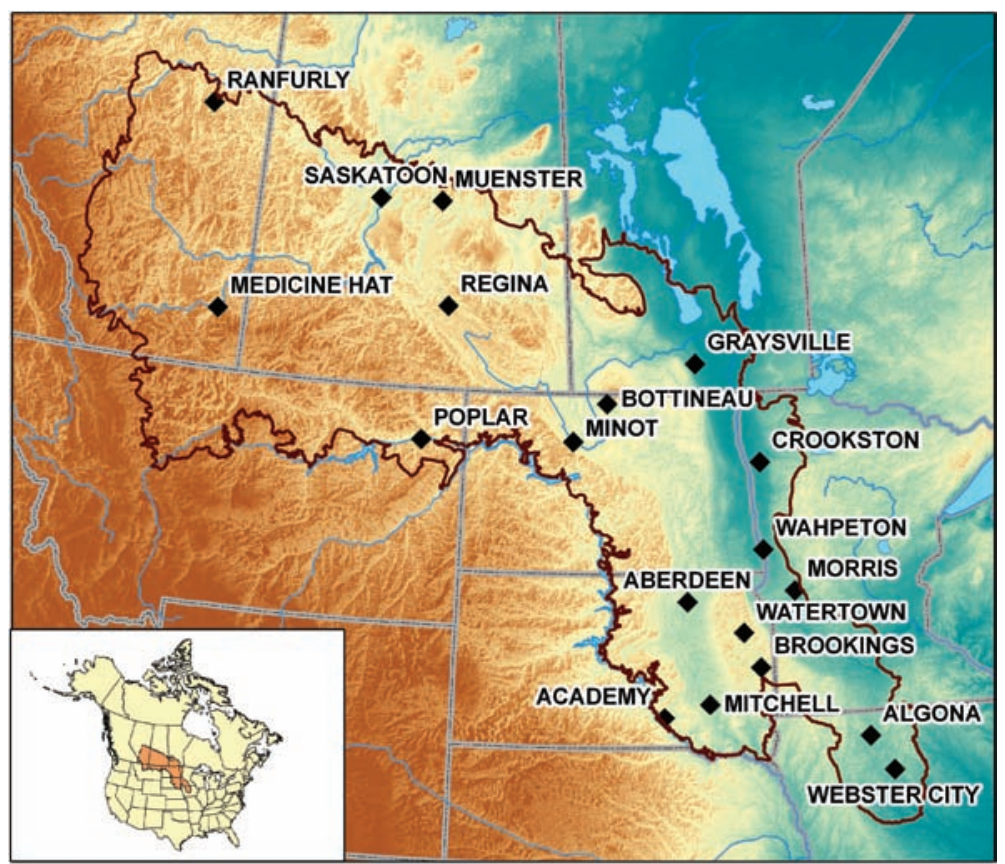

Prairie pothole region

Weather stations

Figure 1. Location of the prairie pothole region within North Amer$i c a$, and the names and locations of long-term weather stations used in this analysis.

abundance of aquatic invertebrates, such as those found very early in the breeding season in temporary and seasonal wetlands, increased waterfowl nesting success. Later in summer, when the more ephemeral wetlands are often dry, semipermanent wetlands provide habitat for waterfowl broods, molting adult ducks, and for other wetland vertebrates such as amphibians that require relatively long hydroperiods to complete their life cycles.

Because of the variability of water conditions over seasons and years, wetland complexes are more likely to have at least some wetlands in a water and plant regime favorable to a given species, thus ensuring diverse species representation in wetland landscapes (Weller 1999). Water birds often build their local habitat units around a wetland complex that provides various needs and also may act as a backup in the event of catastrophic change (Weller 1999). As a result, wetland complexes support higher species richness compared with single, isolated wetlands of comparable total surface area (Naugle et al. 1999).

A key unanswered question is the extent to which climate change might disproportionately affect the understudied, more labile members of the wetland complex, ultimately reducing its overall resilience and ability to support historically high levels of biodiversity and ecosystem services. Winter (2000) proposed that semipermanent wetlands generally found in lower topographic positions, especially those underlain by highly permeable deposits such as sand and gravel, should be less vulnerable than temporary or seasonal wetlands because they are supported by groundwater.

\section{Twentieth-century PPR climate}

The climate of the PPR became warmer and wetter during the 20th century, but these changes were not spatially uniform (Millett et al. 2009). Minimum daily temperatures warmed by 1.0 degree Celsius $\left({ }^{\circ} \mathrm{C}\right)$, while maximum daily temperatures cooled by $0.15^{\circ} \mathrm{C}$. Minimum temperatures warmed more in winter than in summer, whereas maximum temperatures fell in summer and rose in winter. Mean annual precipitation increased by 49 millimeters (mm) (9\%). The strong east-west gradient across the PPR of decreasing moisture toward the rain shadow of the Rocky Mountains steepened during the 20th century, with a small number of stations in the western PPR (particularly in the western Canadian prairies) becoming effectively drier, and a larger number of stations in the eastern PPR becoming effectively wetter.

The PPR warmed during the 20th century at a level similar to the global average; more warming is expected during the 21st century. The Intergovernmental Panel on Climate Change (IPCC 2007) projected that the mean temperature of Earth's atmosphere will increase by $1.8^{\circ} \mathrm{C}$ to $4.0^{\circ} \mathrm{C}$ by the year 2100. A suite of models has produced isocline maps for the approximate PPR (IPCC 2007), projecting temperature increases near $4.0^{\circ} \mathrm{C}$ accompanied by small shifts in precipitation ( $-5 \%$ to $10 \%)$. An intensified hydrologic cycle is also anticipated that will cause increased frequency of both drought and deluge (Ojima et al. 2002, Johnson et al. 2004).

\section{Modeling approach}

This article examines the consequences of a changing climate on wetland complexes in PPR landscapes using a new simulation model. WETLANDSCAPE (WLS) is a climatedriven, process-based, deterministic simulation model. Its predecessor, WETSIM, was the backbone of our previous climate-change research (e.g., Poiani and Johnson 1993, Poiani et al. 1996, Johnson et al. 2005), but it modeled only semipermanent wetlands. The development of WLS allowed for a more comprehensive analysis of the climate-change issue across the northern prairies because it simultaneously simulates wetland surface water, groundwater, and vegetation dynamics of the wetland complex, including multiple wetland basins of semipermanent, seasonal, and temporary permanence types, in addition to overflows between basins.

The key differences between WLS and WETSIM (versions 1.0-3.1) are (a) the simulation of a wetland complex rather than a single, semipermanent basin; (b) the incorporation of a "double-bucket" model structure, allowing for separate calculation of surface water depth and volume and depth to groundwater to model the very different hydrology of the three wetland permanence types (figure 2); (c) a change from a daily to a 10-day time step; (d) the use of STELLA rather than MATHEMATICA (Wolfram 1999) as 


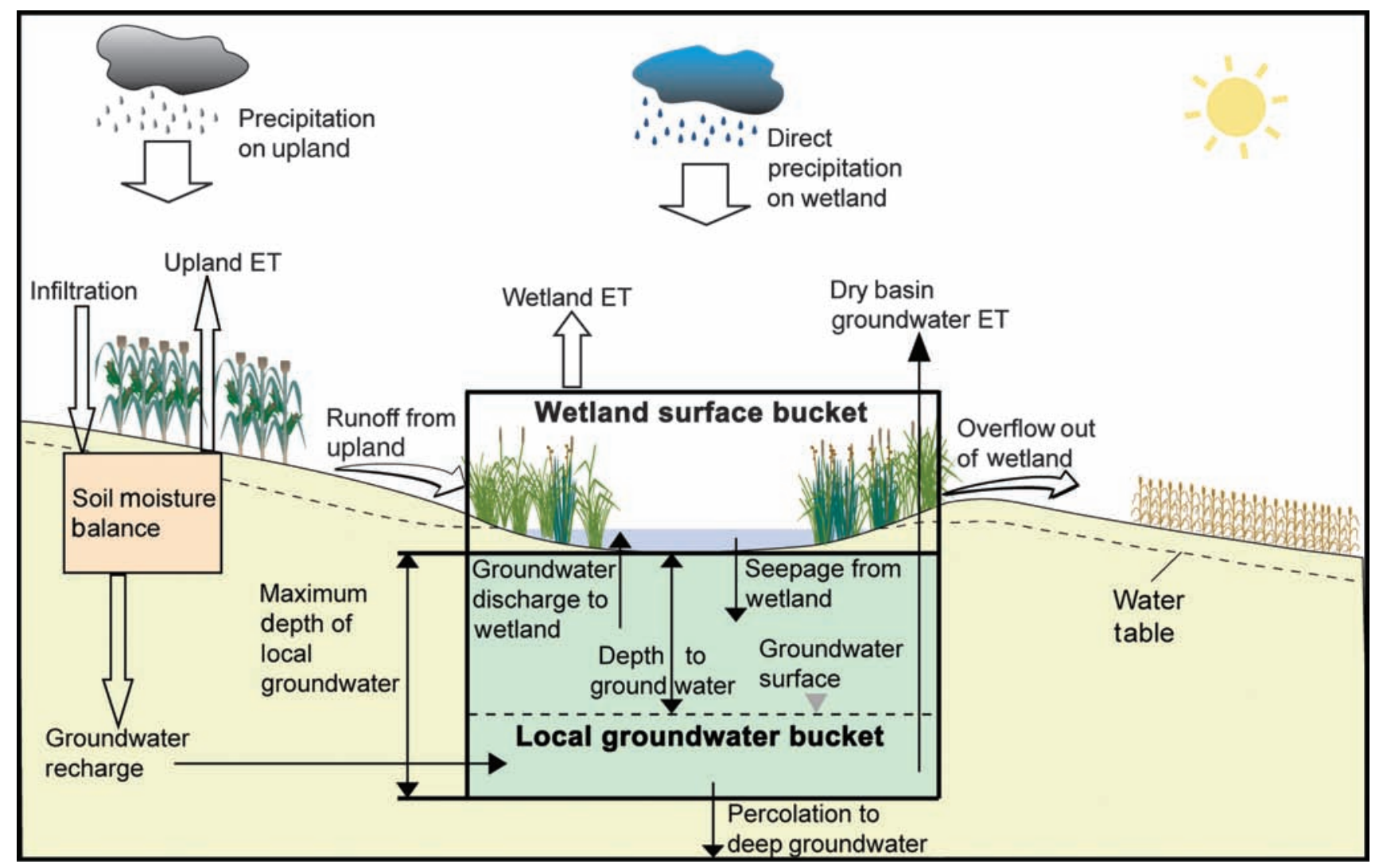

Figure 2. Generalized wetland water budget with double-bucket submodel used in the simulation model WETLANDSCAPE. ET, evapotranspiration.

the modeling software platform (use of trade or product name does not imply endorsement by the US government); and (e) use of the Blaney-Criddle equation to calculate potential evapotranspiration used in WETSIM 2.0 (Poiani et al. 1996), rather than the modified Hargreaves equation used in WETSIM 3.1 (Johnson et al. 2005). We chose the Blaney-Criddle equation because it produced a better fit than did the Hargreaves equation with field data from our Orchid Meadows site. (Refer to Carroll and colleagues [2005] for a full description of the 10-day time-step method using averages of daily inputs of precipitation, minimum and maximum temperature, and the technical aspects of implementing the Blaney-Criddle equation.)

WLS was parameterized and tested using long-term monitoring data from 10 wetlands ( 3 temporaries, 3 seasonals, and 4 semipermanents) and 40 groundwater wells at our Orchid Meadows field site near Clear Lake, South Dakota (Johnson et al. 2004). Model setup required the determination of basin morphometry and overflow connectivity among wetlands. Calibration of the model used 13 years of data for all wetlands (1993-2005), with three additional years of observations (1987-1989) for some basins. The monitoring data included weather extremes of deluge (the early to mid 1990s) and drought (the late 1990s and early 2000s; Johnson et al. 2004). Wetland watersheds were in permanent grass cover with occasional grazing.
WLS successfully modeled the key hydrological properties that distinguished each wetland permanence type, including spring rise, summer drawdown, hydroperiod, and depth to groundwater (figure 3). An exact match between modeled and observed conditions was neither expected nor attainable through calibration because of the mismatch between the 10-day model time step and the two-week field sampling schedule and dependence on off-site primary weather station data for winter precipitation.

Driving wetland models with weather data from many stations has proven to be an instructive proxy for understanding both the temporal and spatial variability of wetland dynamics, and the sensitivity and geographic complexity of the response of prairie wetlands to climate change (Johnson et al. 2005). The range of basin morphometry of the Orchid Meadows wetland complex, however, was less than the range across the PPR.

In summary, our analytical approach was to isolate, to the extent possible, the effect of climate on the condition of the wetland complex by driving WLS, calibrated at Orchid Meadows, with weather data from 19 other PPR stations (figure 1), each with 100 years of data (1905-2004). To improve geographic dispersion of weather stations in our previous analysis (Johnson et al. 2005), we added two stations (Aberdeen, South Dakota, and Regina, Saskatchewan) and dropped one (Clark, South Dakota). We assessed the effects of future climate conditions by adopting three 


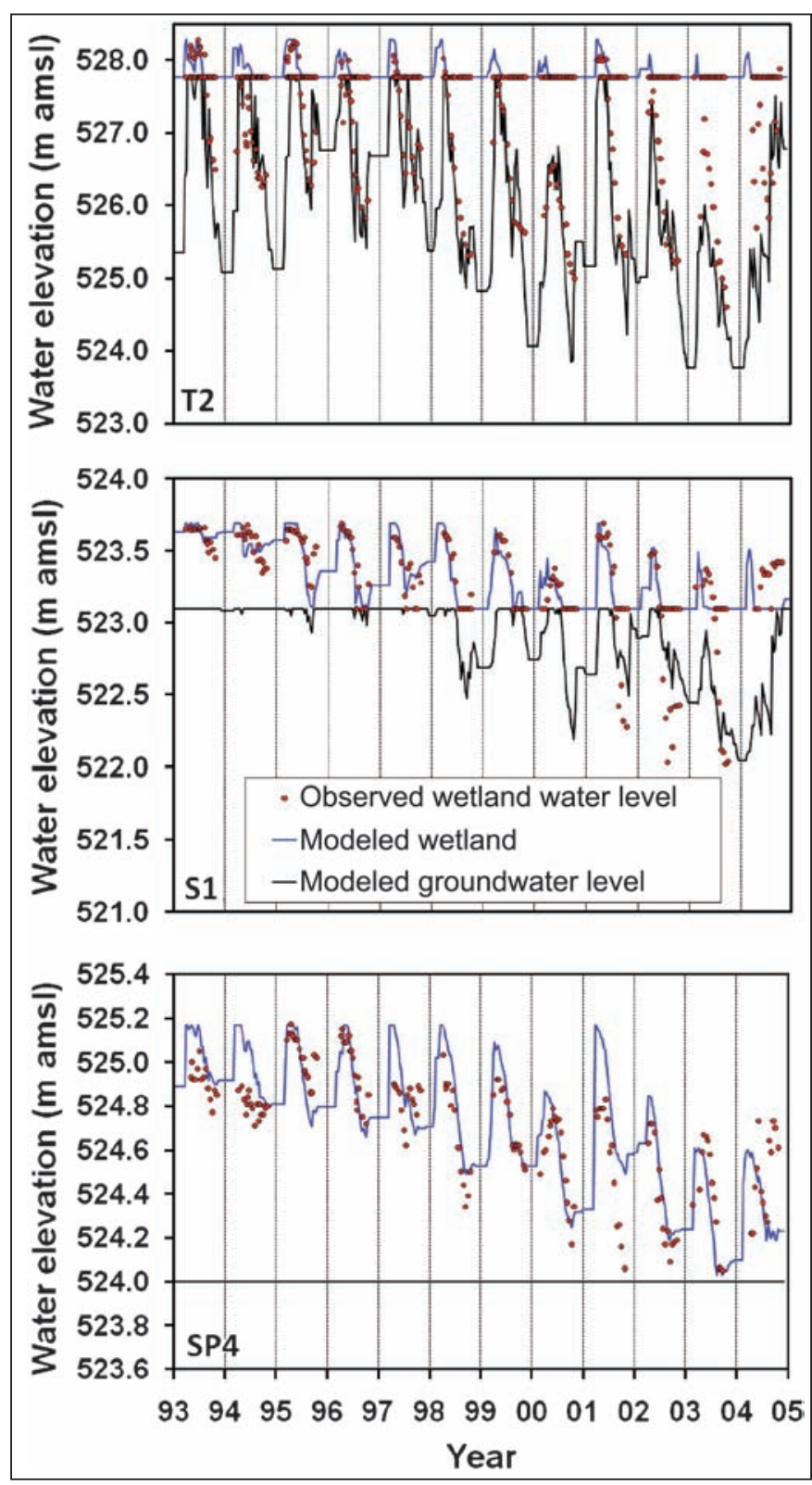

Figure 3. Calibration hydrographs for a temporary (T2), seasonal (S1), and semipermanent (SP4) wetland at the Orchid Meadows, South Dakota, field site over a 12-year period (1993-2004). Horizontal line is the wetland bottom. Elevation is in meters above mean sea level.

climate scenarios $\left(+2^{\circ} \mathrm{C},+4^{\circ} \mathrm{C},+4^{\circ} \mathrm{C}+10 \%\right.$ precipitation $)$ on the basis of projections from global circulation models (IPCC 2007).

\section{Measures of wetland response to climate}

The biodiversity and productivity of wetland complexes are affected by exogenous forces, such as climate, and endogenous forces, such as the mix of permanence types, surficial geology, water regimes, wetland juxtaposition, and vegetation (Weller 1994, 1999, Weller and Fredrickson 1974, Swanson et al. 2003, van der Valk 2005). We quantified the model response to a range of climates using two primary measures or indices: wetland hydroperiod (time of inundation) for each permanence type, and a measure of the dynamism of wetland vegetation for semipermanent wetlands. These modeled responses offer three novel contributions to scientific understanding of climate-wetland interactions: First, they refine and reinforce earlier research on semipermanent basins; second, they fill the research gap on the effects of climate change on more labile wetlands; and third, they simulate the potential effect of climate on wetland complexes-information that was previously unavailable or largely conjectural.

Hydroperiod. Many wetland species require a minimum time of inundation either within a home wetland or across a wetland complex to complete their life cycles. For example, most dabbling ducks (e.g., mallard, teal) require a minimum of approximately 80 to 110 days of surface water for their young to fledge and for breeding adults to complete molting (Bellrose 1980, Austin and Miller 1995). WLS computed the hydroperiod across years for each wetland of the complex to evaluate the effect of historic and alternative future climates on life-history requirements and thresholds for key wetland species or guilds.

Vegetation cover-cycle index. The vegetation cover cycle of semipermanent prairie wetlands has been well studied and modeled. In brief, the drought and deluge frequencies associated with a given climate determine the speed of the nutrient and vegetation cycles (Weller and Spatcher 1965, Murkin et al. 2000). Prolonged high water produces a "lake" wetland with little emergent cover and few nutrients in detritus, whereas persistent low water produces heavy emergent cover and high nutrient sequestering in plant material. The occurrence of both extremes during a weather cycle causes plant population turnover (maintaining biological diversity) and nutrient mobilization. These events have been described as a wetland cover cycle that includes four stages: (1) a dry stage with dense emergent cover and little or no standing water; (2) a regenerating stage with germination from a diverse seed bank, reflooding, and vegetative propagation; (3) a degenerating stage when emergent plants start to decline; and (4) the lake stage with high water and little emergent vegetation (van der Valk and Davis 1978).

The speed of the cover cycle (return time) and the number of switches between cover-cycle stages over a period of time are strongly correlated to productivity and biodiversity (van der Valk and Davis 1978, Swanson et al. 2003). Long return times (one cycle per century) or extended periods without switches produce wetlands "stuck" in either the lake stage or the dry stage with stable, but relatively unproductive, conditions. Weller and Fredrickson (1974) noted that stable water levels produce ornithologically "dead" marshes characterized by a centrally open marsh with a perimeter of dense emergent vegetation. Short return times (e.g., three to 


\begin{tabular}{|c|c|c|c|}
\hline Current stage & New stage & Maximum depth (meters) & Duration \\
\hline Lake marsh & Hemi-marsh & $<0.5$ & May-July \\
\hline Hemi-marsh & Lake marsh & $>0.75$ & 2 years \\
\hline Hemi-marsh & Dry marsh & $<0.1$ & May-July \\
\hline Dry marsh & Hemi-marsh & Between 0.4 and 1.0 & 1.5 years \\
\hline Dry marsh & Lake marsh & $>0.75$ & 2 years \\
\hline
\end{tabular}

four complete cycles per century), however, create the temporal scale environmental heterogeneity necessary for high productivity. Wetlands with short return times more often produce the hemi-marsh conditions desired by wetland managers (approximately equal proportions of emergent cover and open water, resulting from a combination of regenerating and degenerating stages).

We developed a cover-cycle index (CCI, see the equation below) of climate favorability on the basis of two variables of equal weight: (1) the proportion of time, averaged across the three semipermanent WLS wetlands, spent in the hemimarsh stage during a 100-year simulation; and (2) the average number of cover-cycle state changes (i.e., switches) over the same time period. We used a transition probability model to estimate the proportion of time that model wetlands spent in each of the three cover-cycle stages (lake, dry, and hemi-marsh). Transitions between stages were based on water depth classes (table 1) modified from Poiani and Johnson (1993). For the second variable of the index, we recorded and summed each transition that occurred during the simulation between any of the cover stages.

$$
\mathrm{CCI}=\left(H M / H M^{1}+S W / S W^{1}\right) / 2
$$

In the equation above, $H M=$ time in hemi-marsh, $H M^{1}$ $=$ maximum percentage of time in hemi-marsh across weather stations; $S W=$ the number of switches, and $S W^{1}=$ the maximum number of switches across weather stations. The maximum number of switches across all simulations was 21 (Academy, South Dakota-historic), whereas the maximum time spent in the hemi-marsh stage was 51\% (Watertown, South Dakota- $2^{\circ} \mathrm{C}$ ). The highest CCI value was 0.86 at Academy, South Dakota; Algona and Webster City (Iowa) tied for the lowest score of 0.04 . This index is offered as a starting point in quantifying the relationship between climate (and climate change) and prairie wetland productivity.

\section{Modeling labile wetlands and the wetland complex}

WLS captured the contrasting water regimes among monitored wetlands of the Orchid Meadows complex (figure 4). We evaluated three representative wetlands, one from each permanence type, which all exhibited a simultaneous spring rise when the snowpack melted and rain ran off frozen or saturated soil. The semipermanent wetland carried over water from the previous growing season, whereas the more ephem-

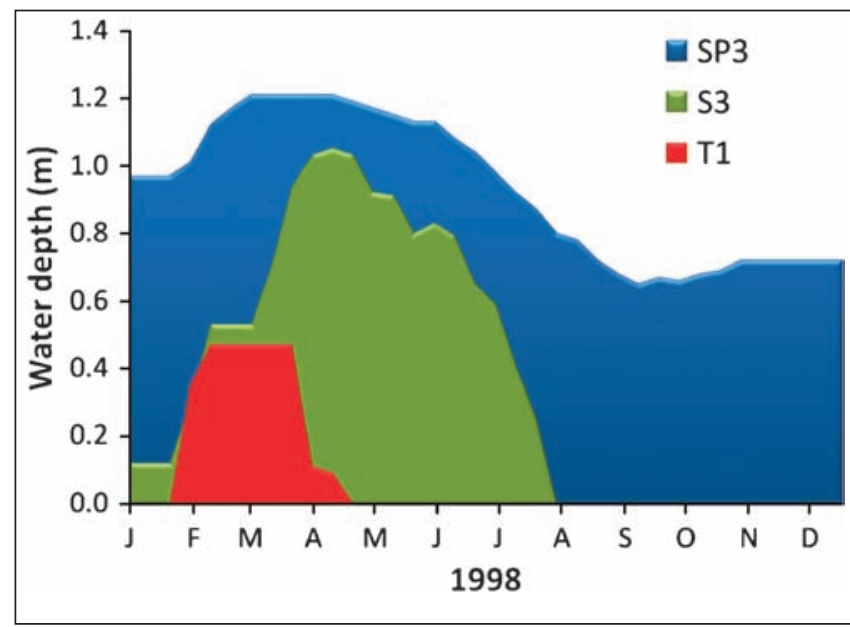

Figure 4. Modeled hydrograph comparisons among a temporary (T1), seasonal (S3), and semipermanent (SP3) wetland by the simulation model WETLANDSCAPE (WLS) from 1998 weather data for the Orchid Meadows field site.

eral permanence types were dry or nearly dry in the fall and winter, but filled from spring runoff. As the weather warmed, the temporary wetland dried up first, because it was the shallowest and leaked to the groundwater (recharge wetland). The deeper and less-leaky seasonal wetland had a considerably longer hydroperiod, especially the particular example we evaluated, with a closed basin and no active outlet (figure 4). The semipermanent wetland had a strong summer drawdown, but carried water over into the next year.

In the historic period simulated by WLS, temporary wetlands had the shortest average hydroperiods (proportion of time wet), ranging from approximately 0.15 to 0.55 among weather stations (figure 5). Expressed as times of inundation, these average hydroperiods ranged from approximately one to two weeks to two months. The shortest hydroperiods occurred at the semi-arid stations in the western PPR, including Montana, Alberta, and Saskatchewan (figure 5), whereas the longest hydroperiods were at the subhumid stations in the southeastern PPR of Iowa and western Minnesota. Seasonal wetlands produced a wider range of hydroperiods than the temporary wetlands, from approximately 0.15 to 0.80 ; the longest hydroperiods were associated with semipermanent wetlands (figure 5). Water depth exhibited a similar geographic pattern. 

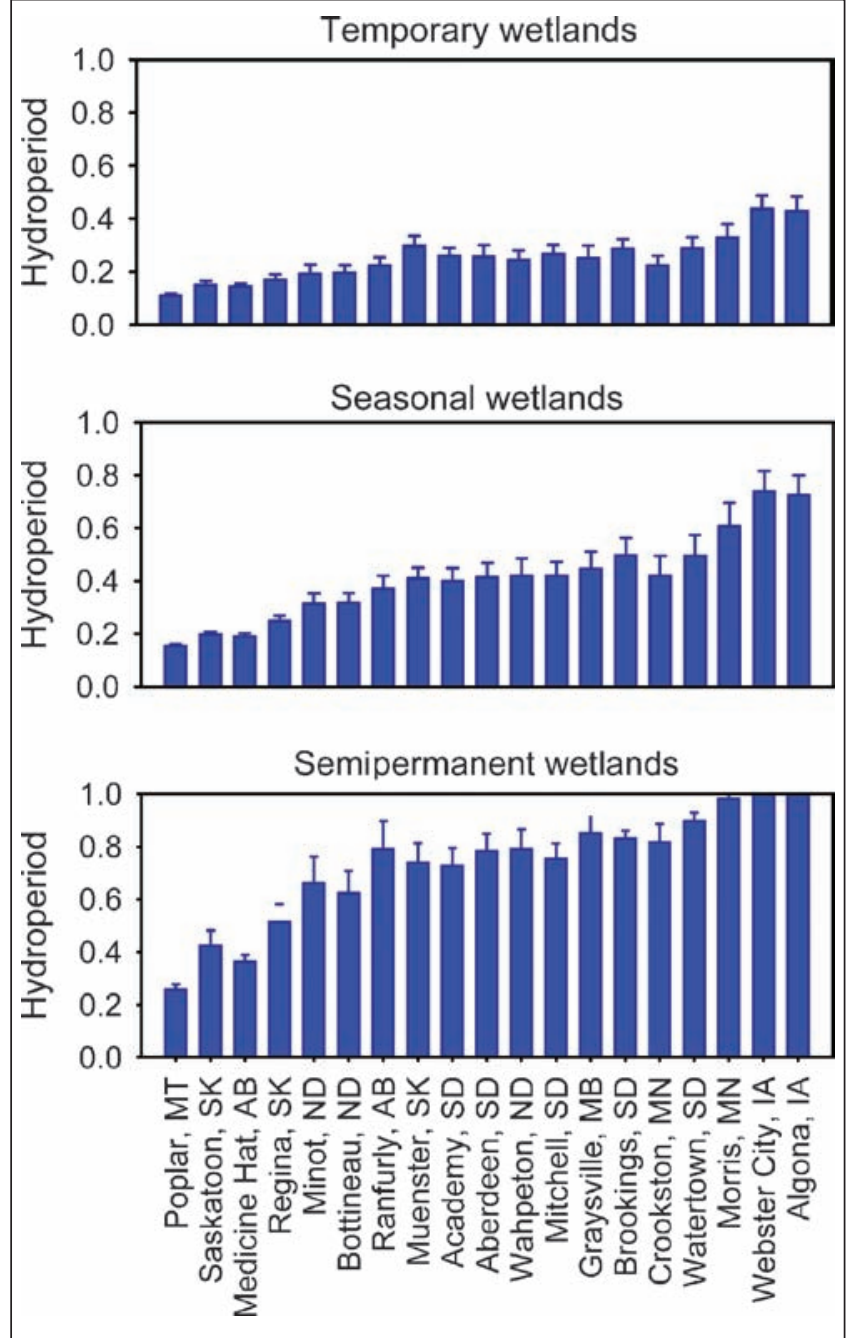

Figure 5. Simulated mean hydroperiod patterns across the prairie pothole region for components of the wetland complex at the Orchid Meadows field site using the simulation model WETLANDSCAPE. Standard error of the mean shown above each bar. See figure 1 for weather station locations.

The contrasts in hydroperiod among the permanence types were very strong; at the large majority of stations, semipermanent wetlands would have historically held deeper standing water for more than half of the open-water season, whereas the standing water for seasonal and temporary wetlands was present for less than half of the open-water season at most stations. Overall, there was a strong geographically based contrast between the simulated hydrological conditions of the wetland complex's basin members. Hydroperiods were much lower on the western, more arid boundaries of the PPR, and much higher on the eastern, more humid fringes.

\section{Results of climate-change simulations}

We explain the results of the WLS simulations for the PPR in the following sections.

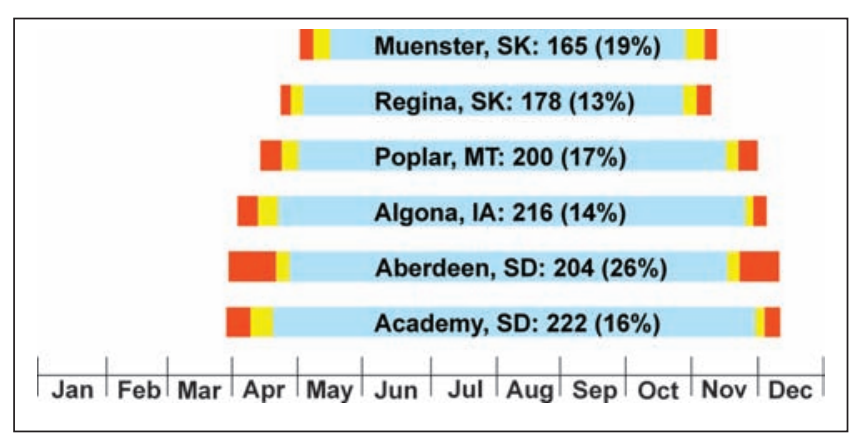

Figure 6. Simulated mean length (using WETLANDSCAPE) of the open-water season at six prairie pothole region weather stations (one from each ecoregion) for historic (1905-2004; width of light blue bar), 2 degrees Celsius $\left({ }^{\circ} \mathrm{C}\right)$ warmer scenario (yellow + light blue bar), and $4^{\circ} \mathrm{C}$ warmer scenarios (red + yellow + light blue bars). Number of open-water days reported for each station, along with percentage increase in open-water days between historic and $4^{\circ} \mathrm{C}$ scenario. Ice-free season air temperature thresholds in spring and fall (10-day average of mean daily air temperature of $3^{\circ} \mathrm{C}$ ).

Open-water season. Earlier ice-out and later freeze dates during the past 150 years have been reported for Northern Hemisphere lakes (Magnuson et al. 2000). Longer ice-free periods are projected in the future with continued climate warming (IPCC 2007). The WLS simulation projected that a surface temperature increase of $4^{\circ} \mathrm{C}$ distributed evenly across months would extend the ice-free season for prairie wetlands by $13 \%$ to $26 \%$ across weather stations (figure 6). WLS used a 10 -day threshold mean daily air temperature of $3^{\circ} \mathrm{C}$ in the spring and fall to estimate the start and end of the open-water season each year. These temperature thresholds were based on ice data at our Orchid Meadows site (Johnson et al. 2004).

Our results suggest that climate warming may produce threshold or nonlinear effects (Burkett et al. 2005) in some PPR climates. Each $2^{\circ} \mathrm{C}$ increment in temperature extended the ice-free season about one model time step (10 days). Spring was advanced more than fall was extended. At Academy, South Dakota, near the southern boundary of the PPR, snowmelt runoff was complete in late March, on average, under a $4^{\circ} \mathrm{C}$ scenario, rather than mid-April under the historic climate. At Muenster, Saskatchewan, near the northern boundary of the PPR, snowmelt runoff would first occur around 1 May instead of mid-May under the historic climate. The percentage increase in the length of the ice-free season was similar among stations (13\% to $19 \%$ ) except for Aberdeen, South Dakota, which exhibited a considerably lengthened ice-free season (26\%), most of which occurred between the $2^{\circ} \mathrm{C}$ and $4^{\circ} \mathrm{C}$ temperature scenarios (figure 6).

Permanence types and water regime. The complexity of the response of the model wetlands to climate-change scenarios 


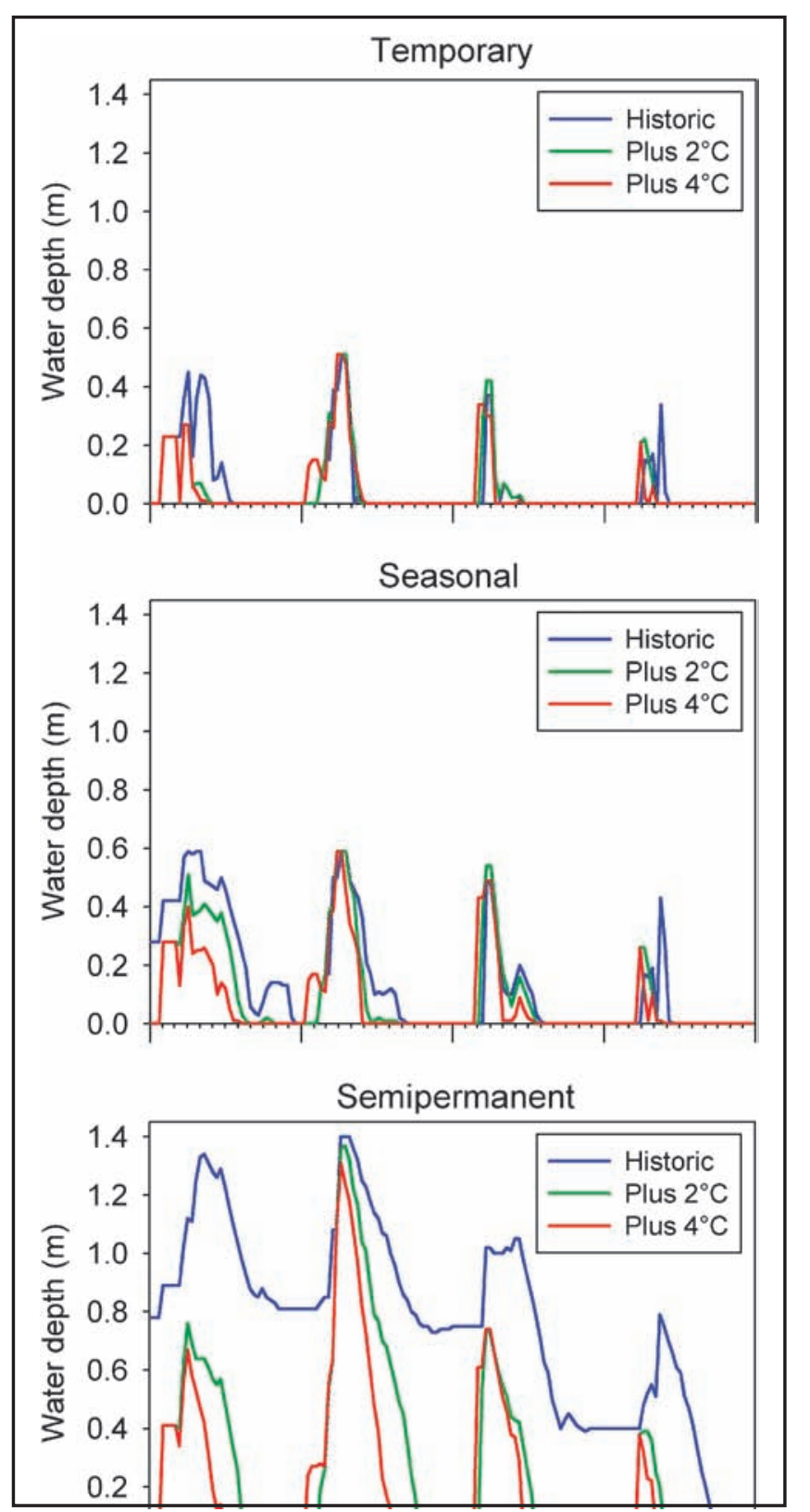

Figure 7. Three annual WETLANDSCAPE (WLS) hydrographs (1986-1989) showing the effect of 2 degrees Celsius $\left({ }^{\circ} \mathrm{C}\right.$ ) and $4^{\circ} \mathrm{C}$ warming scenarios for the depth (in meters [m]) of a temporary, seasonal, and semipermanent wetland from the Orchid Meadows wetland complex.

was particularly evident during periods with variable weather (e.g., 1986-1989). The main consequences of a warmer climate were earlier snowpack melting, reduced wetland water depths and volumes, shorter hydroperiods, faster drawdown, and reduced snowmelt and rainfall peaks (figure 7). The response of WLS to specific precipitation events, however, was quite complex. Model water budgets for each of the simulation years revealed that the primary cause of reduced peaks was greatly reduced runoff because of drier soils in the watershed under a warmer climate. This was a product of greater evapotranspiration in the uplands during the previous year, and of the extended fall and earlier spring water seasons. We programmed runoff curve numbers (Voldseth et al. 2007) in WLS to vary with calculated soil moisture values.

The annual simulations revealed that the effect of higher surface temperatures increased with increasing wetland permanence (figure 7). For example, weather during the years 1986 (especially) and 1987 produced the strongest differences among scenarios for the temporary and seasonal wetlands, whereas the water regime of the semipermanent wetland was greatly altered by the scenarios in all four years of the simulation. The semipermanent wetland dried up each year under the $4^{\circ} \mathrm{C}$ scenario, a behavior more typical of seasonal wetlands in the current climate.

Semipermanent cover-cycle dynamics. Geographic trends in wetland cover-cycle dynamics, as expressed by the CCI, followed a strong longitudinal gradient across the PPR during the historic period (figure 8). Simulations indicated that the most favorable climate for high wetland productivity (highest CCI scores of 0.44 to 1.0 ; dark green in figure 8) would have covered nearly half of the PPR (47\%; table 2) and included virtually all of the eastern Dakotas and portions of southwestern Manitoba, southeastern Saskatchewan, and eastern Alberta, just south of the boreal forest. This general region is known for high production of waterfowl during the 20th century (Reynolds et al. 2006).

The lowest CCI scores ( 0 to 0.22 ; yellow in figure 8 ) were from the western and eastern extremes of the PPR. To the west, northern Montana, southwestern Saskatchewan, and southeastern Alberta form a subregion where wetland and waterfowl productivity would have been strongly limited in most, but not all, years by insufficient moisture and a very long cover-cycle return time over much of the 20th century. In contrast, the low CCI scores in the east, including Iowa and most of southwestern Minnesota, identify a subregion where productivity would have been limited by a slow cover cycle, prolonged lake-marsh conditions, and too much water. Wedged between these categories was a small, light-green area (15.4\%; table 2) of moderate productivity potential.

The warmer climate scenarios produced an eastward shift of all CCI classes (figure 8). The area of yellow with the least favorable climate increased from $37.6 \%$ of the map during the historic period to $39 \%$ and $62.5 \%$ of the map under the $2^{\circ} \mathrm{C}$ and $4^{\circ} \mathrm{C}$ scenarios, respectively (table 2 ). The dark green area of high potential productivity nearly disappeared from the map, shifting to the east and dropping sharply from $47 \%$ in the historic period to $30.8 \%$ and $12.5 \%$, respectively, under the $2^{\circ} \mathrm{C}$ and $4^{\circ} \mathrm{C}$ scenarios (table 2). Under the $4^{\circ} \mathrm{C}$ scenario, nearly all of eastern North Dakota was covered by the driest index scores, while eastern South Dakota retained a more favorable cover-cycle category (figure 8). Overall, the part of the PPR with the highest CCI scores historically was largely transformed under the more extreme climate scenario into a region with low to moderate CCI scores. 

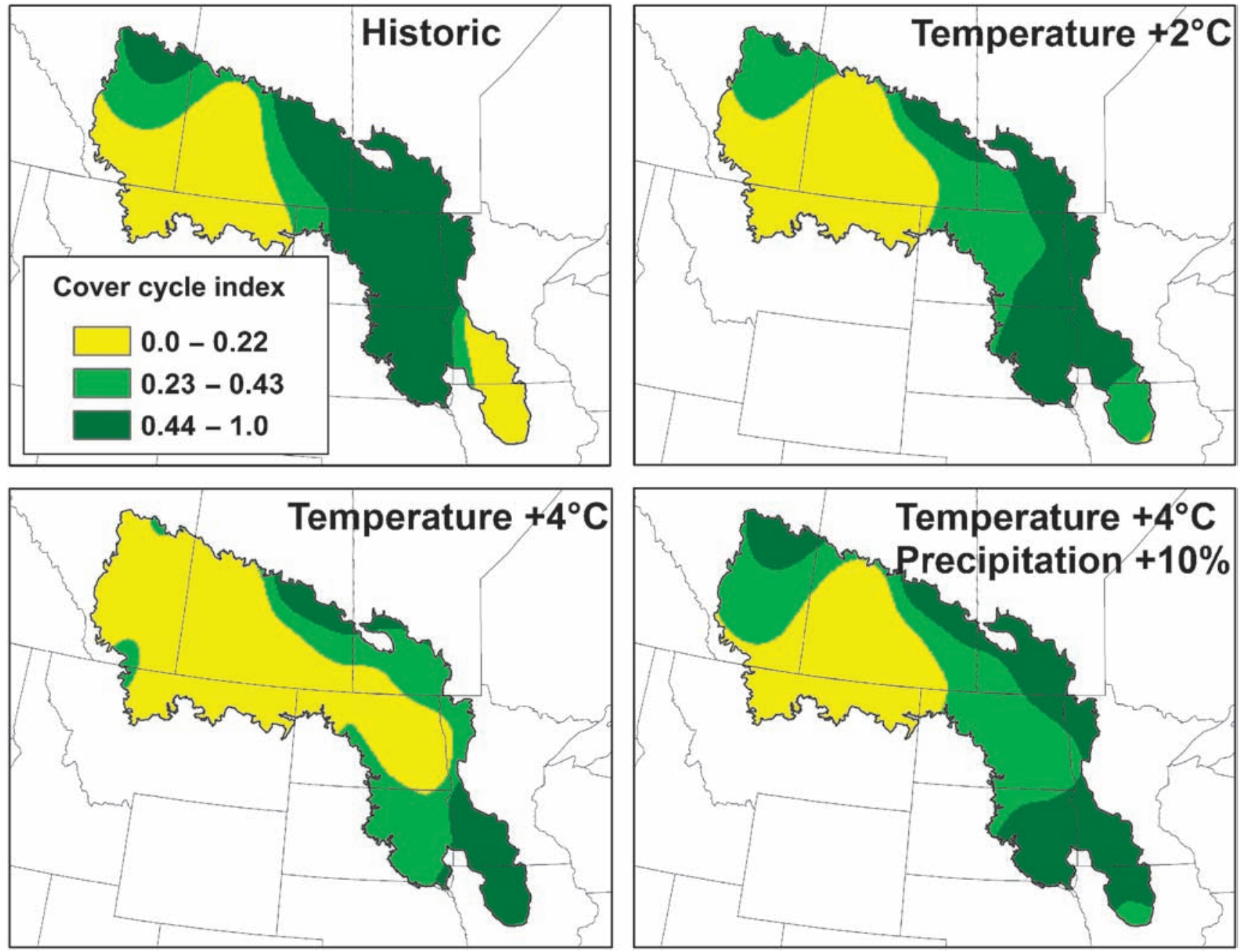

Figure 8. Maps of the cover-cycle index for the prairie pothole region based on historic weather data and three climate scenarios (2 degrees Celsius $\left[{ }^{\circ} \mathrm{C}\right]$ warming; $4^{\circ} \mathrm{C}$ warming; $4^{\circ} \mathrm{C}$ warming and $10 \%$ increase in precipitation).

Eastern portions of the PPR that were historically too wet to produce the highest CCI scores could see improvements under a slightly warmer climate. Under the $2^{\circ} \mathrm{C}$ scenario, the extreme southeastern section of the PPR (Minnesota and Iowa) shifted into the high-productivity category, suggesting that the drier climate could create more desirable water-tocover interspersion ratios and more dynamic wetlands. Similarly, the only part of the PPR with high CCI scores under the $4^{\circ} \mathrm{C}$ scenario was in southwestern Minnesota and Iowa. The WETSIM model produced a similar finding for semipermanent wetlands (Johnson et al. 2005). Increasing precipitation by $10 \%$ virtually canceled out a $2^{\circ} \mathrm{C}$ higher air temperature, a result also found by Voldseth and colleagues $(2007,2009)$. Although greenhouse gases may produce a more favorable wetland climate in this region in the future, it currently has the fewest undrained wetlands (Dahl 1990) and the least amount of waterfowl nesting habitat within the PPR.

Seasonal wetlands in the West. The hindcast CCI analysis by WLS identified a 150 - to 200-kilometer north-south running swath just east of the Missouri River (forming the western PPR boundary in the United States), through both Dakotas and northward into Canada, producing the most productive and dynamic semipermanent wetlands during the 20th century (dark-green polygon in figure 8). The drier, western portion of this swath is occupied by the Missouri Coteau, a dead-ice moraine with the highest wetland densities in the PPR (e.g., Edmunds County, South Dakota, has approximately 45,000 natural wetlands; Johnson and Higgins 1997). Seasonal wetlands comprise $72 \%$ of the wetland area in this county (Johnson and Higgins 1997), providing the foundation for extremely high waterfowl production during wet weather extremes.

The capacity of a landscape to support waterfowl is largely determined by the abundance of seasonal wetlands, because breeding pairs isolate themselves from other individuals of the same species when establishing territory in the spring. More important, seasonal wetlands in places like Edmunds County, South Dakota, are embedded within abundant grassland landscapes that reduce predation and increase nest success, which is a determinant of population growth in mallard ducks (Hoekman et al. 2002). 
Table 2. Percentage of the prairie pothole region in the three cover-cycle index categories under historic and scenario climates. The climatic region producing the most dynamic wetlands was dark green; moderately dynamic, light green; and least dynamic, yellow (see figure 8).

\begin{tabular}{lcccc}
\hline Simulation & Dark green & Light green & Yellow & Total \\
\hline Historic & 47.0 & 15.4 & 37.6 & 100.0 \\
Plus $2^{\circ} \mathrm{C}$ & 30.8 & 30.2 & 39.0 & 100.0 \\
Plus $4^{\circ} \mathrm{C}$ & 12.5 & 25.0 & 62.5 & 100.0 \\
Plus $4^{\circ} \mathrm{C}+10 \%$ & 32.5 & 35.0 & 32.5 & 100.0 \\
\hline
\end{tabular}

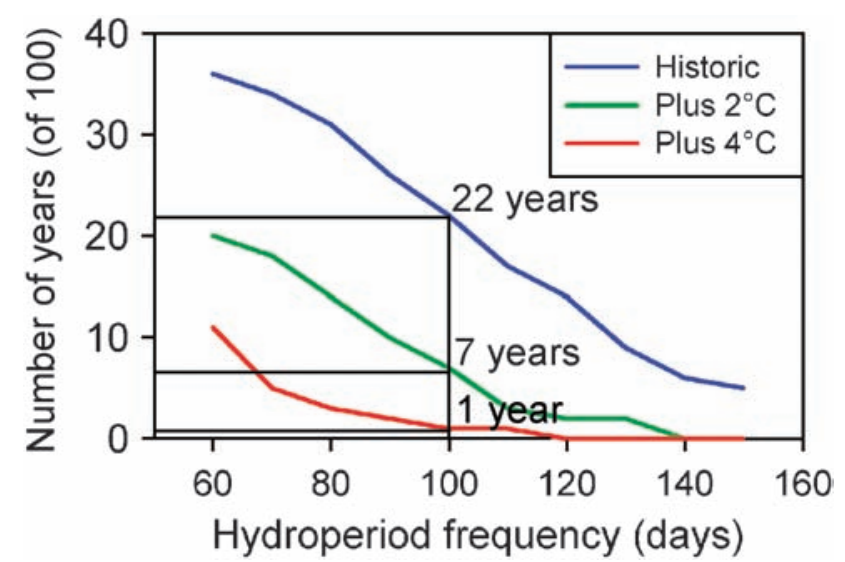

Figure 9. Annual hydroperiod frequency calculated using WETLANDSCAPE for seasonal wetland S1 and a 100-year weather data set and two climate scenarios for the Minot, North Dakota, weather station. A 100-day hydroperiod (vertical bar) approximates the average minimum hydroperiod necessary for many waterfowl and amphibians (e.g., leopard frog) to complete their life cycles.

Simulations with WLS indicate that substantial reductions in the hydroperiod of seasonal wetlands would accompany climate warming on or near the Missouri Coteau. Simulations for the Minot, North Dakota, weather station using seasonal wetland S1 (median of three model seasonal wetlands) produced a curve of hydroperiod frequency during the 20th century (figure 9). Annual hydroperiods of at least 60 days would have occurred in nearly $40 \%$ of the years, whereas lengths of 150 days would have occurred in only about $5 \%$ of the years. A hydroperiod of 100 days, a duration that generally corresponds to the median value for many vertebrates, including waterfowl (Bellrose 1980) and amphibians (Wagner 1997), to complete minimum life-history requirements, would have occurred in 22 of 100 years. Some dabbling ducks such as pintails can complete their breeding cycle (pairing, incubation, brood rearing, fledging, molting) in as few as 70 days (Austin and Miller 1995), while some diving ducks, such as canvasbacks, require a minimum of 130 days (Bellrose 1980).

A $2^{\circ} \mathrm{C}$ warmer climate cut the 100 -day annual hydroperiod frequency by two-thirds, from 22 years to 7 years (figure 9). A $4^{\circ} \mathrm{C}$ warmer climate nearly eliminates a hydroperiod equal to or longer than 100 days. Thus, in only 1 of 100 years

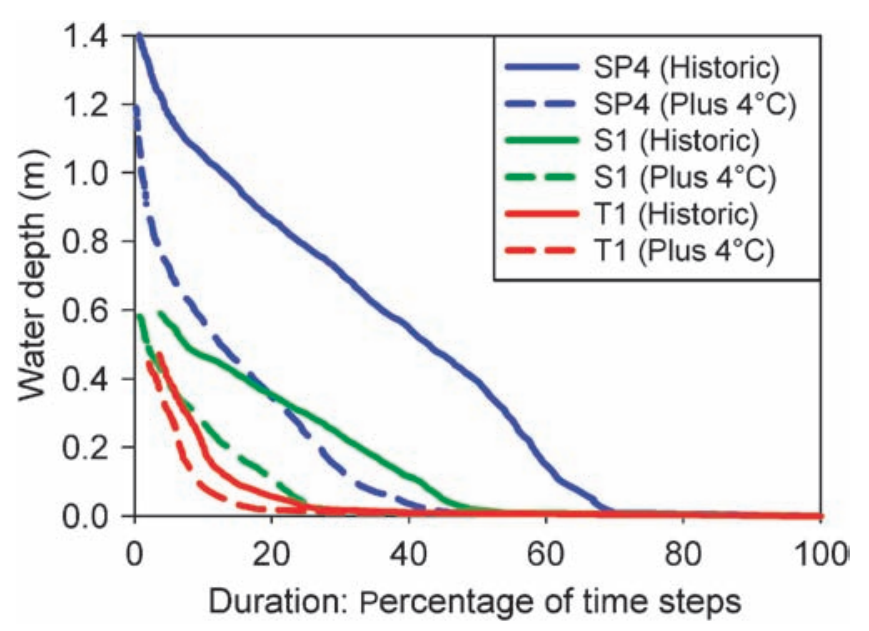

Figure 10. A comparison of wetland stage-duration curves from the simulation model WETLANDSCAPE for historic climate and a 4 degrees Celsius climate change scenario for the Academy, South Dakota, weather station.

under the warmest scenario would this model wetland have an annual hydroperiod of sufficient length to enable many wetland vertebrate species reliant on seasonal wetlands to complete their life cycles. The shallow depth, high ratio of surface area to volume, presence of surface water in summer when evaporative demand is the highest, and weak groundwater support make seasonal wetlands perhaps the most vulnerable of the wetland complex to climate warming. Although semipermanent wetlands with a naturally longer hydroperiod would provide some alternative habitat for seasonal wetlands in marginally dry years, their small areal extent in the western PPR would not make up the difference.

Water-depth frequency analysis. The effect of a warmer climate on the hydrology of prairie wetlands can be visualized by the construction of wetland stage (depth) duration curves (Price 1994). For example, during the historic period at Academy, South Dakota (the station that produced the most dynamic wetlands), semipermanent wetland SP had a depth exceeding 50 centimeters $(\mathrm{cm})$ nearly $50 \%$ of the time (figure 10$)$. Under a seasonally uniform warming of $4^{\circ} \mathrm{C}$, a depth exceeding $50 \mathrm{~cm}$ occurred less than $20 \%$ of the time. For seasonal wetland S1, water depths exceeding $25 \mathrm{~cm}$ declined in frequency under the $4^{\circ} \mathrm{C}$ scenario from approximately $30 \%$ to $15 \%$; for 
temporary wetland $\mathrm{T} 1$, frequency at that depth dropped from approximately $10 \%$ to $7 \%$ (figure 10 ). Overall, the warmer scenario reduced the time spent by all wetland permanence types at the greater water depths, but the magnitude of the effect was directly related to wetland hydroperiod, with the semipermanent and seasonal wetlands being affected the most, and the temporary wetland the least.

Wetlands of the complex also shifted permanence type in response to a warmer climate. Under the $4^{\circ} \mathrm{C}$ scenario, the semipermanent wetland exhibited depth frequencies nearly identical to the seasonal wetland in the historic climate, and the seasonal wetland under the same scenario closely matched the duration curve of the temporary wetland. Thus, a $4^{\circ} \mathrm{C}$ warming was sufficient to change the water regime of a future semipermanent wetland into that of a historic seasonal, and a future seasonal wetland into that of a historic temporary.

\section{Resilience of the prairie wetland complex}

The respective responses of members of the wetland complex to climate change were not as predicted or expected. Several major factors determined the responses. First, water regime characteristics track each other across permanence types because wetlands in the complex experience nearly identical weather, which leads to a moderately coordinated response among members of the complex to weather variability. Second, other factors produce individuality among wetlands and wetland types in their water regimes and responses to climate change. These are mostly physiographic factors such as catchment area, slope, soils, and patterns of snow accumulation that affect the downslope delivery of precipitation to the wetland. Groundwater relations are a third factor as described by Winter (2000). Vegetation and land use contribute to a fourth factor that is correlated with physiographic factors that mainly affect evapotranspiration and runoff (van der Kamp et al. 2003, Voldseth et al. 2007). Hence, this multiplicity of factors, some of which are relatively fixed in space (the environmental template or physiographic setting), and others that are quite variable in both space and in time, complicates the response of the individual wetlands of the complex to climate change, but in combination, these factors create the incredibly diverse and rich heterogeneity in pattern and process across prairie wetland landscapes.

Evidence from modeling, however, revealed identifiable patterns of response by the three wetland types to climate change. First was the unexpectedly greater resiliency of temporary wetlands, the most labile of the classes. The model temporaries recharged with water in the spring under all scenarios at nearly historic levels under our assumption of uniform temperature increases across seasons. Once recharged, temporaries lost water through evapotranspiration and groundwater recharge. Greater evapotranspiration rates in a warmer climate produced shorter hydroperiods than under simulated historic conditions; however, the shortening was less than expected-a given increment of air temperature affected evapotranspiration rates less in spring, when temporaries hold water, than in summer, when they do not. To illustrate, WLS calculated that a $4^{\circ} \mathrm{C}$ increase in air temperature at the Minot weather station in 1982, a representative year, increased the rate of average daily surface water evapotranspiration from model wetland SP4 less in May (1.6 mm per day) than in July (3.7 $\mathrm{mm}$ per day). Thus, by naturally drying out by late spring in most years, temporary wetlands escape the more severe consequences of a warmer climate in summer. It was counterintuitive that small, shallow recharge wetlands would be more resilient to climate warming than deeper discharge wetlands. This apparent resilience of temporary wetlands, however, could be lessened with different assumptions about the future seasonality of temperature and precipitation. Winters that warm more than summers, as are projected for many regions (IPCC 2007), would increase sublimation and reduce snowpack, thus lowering the spring rise and shortening hydroperiods.

Conversely, semipermanent wetlands that usually have standing water in the hottest part of the growing season were relatively more affected by the disproportionately higher evapotranspiration rates than were temporary wetlands. Greater evapotranspiration losses occurred in both the wetland itself and in the catchment. The WLS simulation adjusts runoff according to soil moisture levels. Percent reductions in runoff, however, were greatest for semipermanent wetlands because of the much drier soils in a greenhouse climate in the summer compared with spring.

The disproportionate effects of warming on semipermanent wetlands have major consequences for vertebrates by greatly shortening the length of the hydroperiod for the whole complex. This model result contrasts with Winter's (2000) assessment that semipermanent wetlands will be the most resilient permanence type to climate change because they have more groundwater support, especially those in glacial deposits with high permeability. Clearly, a wetland is semipermanent because of groundwater support (Winter and Rosenberry 1995, van der Kamp and Hayashi 2009); however, it appears from our modeling that the effect of this "bonus" water, if locally derived, is depleted quite quickly in long-term simulations under chronically warmer climates that cause a permanence type shift to the seasonal class. van der Kamp and Hayashi (1998) reported that extended periods of drought led to a lowering of the local water table around the wetland.

The influence of groundwater on wetland permanence depends on the permeability of glacial deposits associated with the wetland basin. Winter and Woo (1990) estimated that groundwater supplied $5 \%$ to $25 \%$ of the water input to semipermanent wetlands. Carroll and colleagues (2005) estimated that groundwater contributed $19 \%$ of the inflow to their model wetland. Modeled groundwater inflows for the semipermanent wetlands at Orchid Meadows ranged from $4 \%$ to $15 \%$ percent of the water budget. This range suggests that our WLS semipermanent wetlands occupied glacial deposits from low to moderate permeability. Had some of our model wetlands been associated with highly 
permeable glacial deposits contributing $15 \%$ to $25 \%$ percent of the water budget, the modeled effects of climate warming on semipermanent wetlands may have been less severe.

\section{Conclusions and recommendations}

WLS simulations (figure 10) showed that all three permanence types of wetlands lost significant hydroperiod under both $2^{\circ} \mathrm{C}$ and $4^{\circ} \mathrm{C}$ warming scenarios, unless accompanied by a minimum increase in precipitation of $5 \%$ to $7 \%$ per degree of warming. These results strongly indicate that the prairie wetland complex is, as a unit, highly vulnerable to climate warming of the magnitude projected by global circulation models (IPCC 2007). None of the permanence types of the complex escapes serious water regime consequences under these climate scenarios.

Our model experiments suggest that the vulnerability of the members of prairie wetland complexes to climate warming and drying, as defined by our scenarios, generally increases in this order: temporary wetlands, semipermanent wetlands, seasonal wetlands. The modeling results for seasonal wetlands were the most alarming, particularly in the western PPR, where they are often the wetlands with the longest hydroperiod in the complexes, and as such, on which vertebrates depend to complete their relatively long life cycles. The highly evaporative summertime greenhouse climate will "push back" hard against the extended hydroperiods of seasonal wetlands made in wet springs. All but the very wettest of the historic "boom" years for waterfowl production in the more arid regions of the PPR may be "bust" years in a $4^{\circ} \mathrm{C}$ warmer climate.

This pattern of accelerated drying raises additional concerns for the future conservation of waterfowl populations. Waterfowl have already altered timing of their migration to arrive earlier on the breeding grounds (Murphy-Klassen et al. 2005), but the key to maintaining populations will be in their ability to adapt to earlier drying after their arrival. Early drying may be an ecological trap (Schlaepfer et al. 2002, Battin 2004), whereby migrating ducks are attracted to wet basins in early spring but cannot fledge their young when wetlands dry up too quickly in the more evaporative greenhouse climate. Survival of mallard ducklings in North Dakota was 7.6 times lower when fewer seasonal wetlands were available during drought than when water was abundant in these same wetlands in subsequent years (Krapu et al. 2006). Indeed, the functional loss of the many wetlands that attract ducks to breeding grounds in spring makes it difficult to imagine how to maintain waterfowl populations at today's levels under an altered climate. Sorenson and colleagues (1998) estimated that a doubling of carbon dioxide could cut the US mid-continent breeding duck population in half, from an average of 5 million to between 2.1 million and 2.7 million birds.

Climate change also poses a conservation challenge farther east, along the fringe of the PPR in Iowa and Minnesota, where virtually all wetlands have been drained and grasslands have been plowed for agricultural production. Before tillage, this region provided favorable breeding opportunities for waterfowl escaping the more frequent droughts in the western PPR. Ironically, the effects of climate change are projected by our research to greatly increase the frequency and severity of drought in the western PPR, where the highest wetland densities and most grassland nesting habitats are currently found. Mitigation in the eastern PPR is problematic because of the high cost of wetland and grassland restoration where land prices and crop production are the highest in the PPR.

The WLS simulations provide wetland scientists with their first look at prairie wetland complexes in future greenhouse climates. Improvements in modeling and climate predictability are needed and ongoing; however, the body of research conducted thus far on prairie wetlands and climate variability and climate change by both us (e.g., Poiani and Johnson 1991, Poiani et al. 1996, Johnson et al. 2005, Millett et al. 2009, Voldseth et al. 2009) and by others (Larson 1995, Covich et al. 1997, Clair 1998, Sorenson et al. 1998, Winter 2000) has reached similar conclusions on the seriousness of the problem, despite different analytical approaches. The main points are: (a) prairie wetlands in general are highly sensitive to climate warming; (b) wetlands in the drier, western PPR are most vulnerable to climate warming; (c) members of the wetland complex will respond differently to climate change, and longer-hydroperiod wetlands are perhaps the most sensitive; (d) shortened wetland hydroperiods will severely affect vertebrates because of their longer life-cycle requirements; (e) in a greenhouse climate, more of the PPR will be too dry or without functional wetlands and nesting habitat to support historic levels of waterfowl breeding; and (f) adaptation of farming practices in wetland watersheds may buffer the effects of climate change on wetlands.

These findings appear solid enough to serve as the foundation from which to develop management plans to prepare for and adapt to climate change in the PPR as recommended by wildlife conservation groups (Anderson and Sorenson 2001, Galley 2004). Adaptive management would greatly benefit from a larger network of long-term wetland monitoring sites in the PPR that could better detect early signs of warming on water levels and hydroperiod, and to serve as a test for model projections (Conley and van der Kamp 2001). Only three long-term wetland monitoring field sites are currently operational to assist in detecting future trends (van der Kamp and Hayashi 2009). The climate and wetlands of the PPR should be watched more closely in the future to look for signs of higher evaporative demand and reduced hydroperiod to prepare for a PPR with less-productive wetlands and fewer waterfowl (Millett et al. 2009).

Our findings on climate change and prairie wetlands can be applied to other wetland ecosystems beyond North America only in very general terms, because of the stunning heterogeneity of wetland ecosystems globally (Mitsch and Gosselink 2007, Keddy et al. 2009). However, our analytical approach, in which hydrologically driven ecological simulation models are developed, parameterized, and tested at long-term research and monitoring sites and then scaled up to landscapes and regions, can be applied to diverse wetland 
ecosystems. Once hydrology is modeled successfully, the next challenge is to link hydrology directly to species populations, guilds, and communities of organisms - the ultimate goal of ecological research. We continue on this path and anticipate integrating our findings with those of other groups to complete a broader geographical synthesis of the effects of climate change on wetland ecosystems worldwide.

\section{Acknowledgments}

This work was funded by the US Geological Survey, Biological Resources Division Climate Change Program; and by the US Environmental Protection Agency (EPA), Science to Achieve Results (STAR) program, managed by the EPA's Office of Research and Development, National Center for Environmental Research. STAR research supports the agency's mission to safeguard human health and the environment. Tom Tornow, of the US Fish and Wildlife Service in Madison, South Dakota, has made the Orchid Meadows field site (Severson Waterfowl Production Area) available to our project on a long-term basis. Susan Boettcher assisted in field data collection at Orchid Meadows for many years. We acknowledge the foundational research in prairie wetland ecology by Karen Poiani, George Swanson, Arnold van der Valk, Milton Weller, and Thomas Winter.

\section{References cited}

Anderson MG, Sorenson LG. 2001. Global climate change and waterfowl: Adaptation in the face of uncertainty. Transactions of the North American Wildlife and Natural Resources Conference 66: 307-319.

Austin JE, Miller M. 1995. Northern pintail (Anas acuta). In Poole A, ed. The Birds of North America Online. Cornell Laboratory of Ornithology. (3 December 2009; http://bna.birds.Cornell.edu/bna)

Battin J. 2004. When good animals love bad habitats: Ecological traps and the conservation of animal populations. Conservation Biology 18: 1482-1491.

Bellrose FC. 1980. Ducks, Geese, and Swans of North America. 3rd ed. Stackpole.

Brown M, Dinsmore JJ. 1986. Implications of marsh size and isolation for marsh bird management. Journal of Wildlife Management 50: 392-397.

Burkett VR, et al. 2005. Nonlinear dynamics in ecosystem response to climatic change: Case studies and policy implications. Ecological Complexity 2: 357-394.

Carroll R, Pohll G, Tracy J, Winter TC, Smith R. 2005. Simulation of a semipermanent wetland basin in the Cottonwood Lake Area, east-central North Dakota. Journal of Hydrologic Engineering 10: 70-84.

Clair TA. 1998. Canadian freshwater wetlands and climate change. Climatic Change 40: 163-165.

Conley FM, van der Kamp G. 2001. Monitoring the hydrology of Canadian prairie wetlands to detect the effects of climate change and land use changes. Environmental Monitoring and Assessment 67: 195-215.

Covich AP, Fritz SC, Lamb PJ, Marzolf RD, Matthews WJ, Poiani KA, Prepas EE, Richman MB, Winter TC. 1997. Potential effects of climate change on aquatic ecosystems of the Great Plains of North America. Hydrological Processes 11: 993-1021.

Dahl TE. 1990. Wetlands losses in the United States 1780's to 1980's. US Fish and Wildlife Service National Wetlands Inventory Project.

Fairbairn SE, Dinsmore JJ. 2001. Local and land scape-level influences on wetland bird communities of the prairie pothole region of Iowa, USA. Wetlands 21: 41-47.

Galley KEM, ed. 2004. Global Climate Change and Wildlife in North America. The Wildlife Society. Technical Review 04-2.
Gleason RA, Laubhan MK, Euliss NH. 2008. Ecosystem Services Derived from Wetland Conservation Practices in the United States Prairie Pothole Region with an Emphasis on the US Department of Agriculture Conservation Reserve and Wetlands Reserve Programs. US Geological Survey. Professional Paper 1745.

Hoekman ST, Mills LS, Howerter DW, Devries JH, Ball IJ. 2002. Sensitivity analysis of the life cycle of mid-continent mallards. Journal of Wildlife Management 66: 883-900.

[IPCC] Intergovernmental Panel on Climate Change. 2007. Climate Change 2007: The Physical Science Basis. Cambridge University Press.

Johnson RR, Higgins KF. 1997. Wetland Resources of Eastern South Dakota. South Dakota State University.

Johnson WC, Boettcher SE, Poiani KA, Guntenspergen GR. 2004. Influence of weather extremes on the water levels of glaciated prairie wetlands. Wetlands 24: $385-398$.

Johnson WC, Millett BV, Gilmanov T, Voldseth RA, Guntenspergen GR, Naugle DE. 2005. Vulnerability of northern prairie wetlands to climate change. BioScience 55: 863-872.

Keddy PA, Fraser LH, Solomeshch AI, Junk WJ, Campbell DR, Arroyo MTK, Alho CJR. 2009. Wet and wonderful: The world's largest wetlands are conservation priorities. BioScience 59: 39-51.

Krapu GL, Pietz PJ, Brandt DA, Cox RR Jr. 2006. Mallard brood movements, wetland use, and duckling survival during and following a prairie drought. Journal of Wildlife Management 70: 1436-1444.

Kundzewicz ZW, Mata LJ, Arnell N, Döll P, Kabat P, Jiménez B, Miller K, Oki T, Sen Z, Shiklomanov I. 2007. Freshwater resources and their management. Climate Change 2007: Impacts, Adaptation and Vulnerability. Cambridge University Press.

Larson D. 1995. Effects of climate on numbers of northern prairie wetlands. Climatic Change 30: 169-180.

Magnuson JJ, et al. 2000. Historical trends in lake and river ice cover in the Northern Hemisphere. Science 289: 1743-1746.

[MEA] Millennium Ecosystem Assessment. 2005. Ecosystems and Human Well-being: Wetlands and Water Synthesis. World Resources Institute.

Millett BV, Johnson WC, Guntenspergen GR. 2009. Climate trends of the North American prairie pothole region 1906-2000. Climatic Change 93: 243-267.

Mitsch WJ, Gosselink JG. 2007. Wetlands. 4th ed. Wiley.

Murkin H, van der Valk AG, Clark WR. 2000. Prairie Wetland Ecology: The Contribution of the Marsh Ecology Research Program. Iowa State University Press.

Murphy-Klassen HM, Underwood TJ, Sealy SG, Czyrnyj AA. 2005. Longterm trends in spring arrival dates of migrant birds at Delta Marsh, Manitoba, in relation to climate change. The Auk 122: 1130-1148.

Naugle DE, Higgins KF, Nusser SM, Johnson WC. 1999. Scale-dependent habitat use in three species of prairie wetland birds. Landscape Ecology 14: 267-276.

Naugle DE, Johnson RR, Estey ME, Higgins KF. 2001. A landscape approach to conserving wetland bird habitat in the Prairie Pothole Region of eastern South Dakota. Wetlands 21: 1-17.

Ojima DS, Lackett JM. 2002. Preparing for a Changing Climate: The Potential Consequences of Climate Variability and Change-Central Great Plains. Central Great Plains Steering Committee and Assessment Team, Colorado State University.

Poiani KA, Johnson WC. 1991.Global warming and prairie wetlands: Consequences for waterfowl habitat. BioScience 41: 611-618.

. 1993. A spatial simulation model of hydrology and vegetation dynamics in semi-permanent prairie wetlands. Ecological Applications 3: 279-293.

Poiani KA, Johnson WC, Winter TC, Swanson G. 1996. Climate change and northern prairie wetlands: Simulations of long-term dynamics. Limnology and Oceanography 41: 871-881.

Price JS. 1994. Water level regimes in prairie sloughs. Canadian Water Resources Journal 19: 95-106.

Reynolds RE, ShafferTL, Loesch CR, Cox RR Jr. 2006. The farm bill and duck production in the prairie pothole region: Increasing the benefits. Wildlife Society Bulletin 34: 963-974. 
Schlaepfer MA, et al. 2002. Ecological and evolutionary traps. Trends in Ecology and Evolution 17: 474-480.

Sorenson LG, Goldberg R, Root TL, Anderson MG. 1998. Potential effects of global warming on waterfowl populations breeding in the northern Great Plains. Climatic Change 40: 343-369.

Stewart RE, Kantrud HA. 1978. Classification of Natural Ponds and Lakes in the Glaciated Prairie Region. Bureau of Sport Fisheries and Wildlife, US Fish and Wildlife Service. Resource Publication 92.

Swanson GA, Meyer MI, Adomaitis VA. 1985. Foods consumed by breeding mallards on wetlands of south-central North Dakota. Journal of Wildlife Management 49: 197-203.

Swanson GA, Euliss NH, Hanson B, Mushet DM. 2003. Dynamics of a prairie pothole wetland complex: Implications for wetland management. Pages 55-94 in Winter TC, ed. Hydrological, Chemical, and Biological Characteristics of a Prairie Pothole Wetland Complex under Highly Variable Climate Conditions- the Cottonwood Lake Area, East-Central North Dakota. US Geological Survey. Professional Paper 1675.

van der Kamp G, Hayashi M. 1998. The groundwater recharge function of small wetlands in the semi-arid northern prairies. Great Plains Research 8: $39-56$.

. 2009. Groundwater-wetland ecosystem interaction in the semiarid glaciated plains of North America. Hydrogeology Journal 17: 203-214.

van der Kamp G, Hayashi M, Gallen D. 2003. Comparing the hydrology of grassed and cultivated catchments in the semi-arid Canadian prairies. Hydrological Processes 17: 559-575.

van der Valk AG. 2005. Water-level fluctuations in North American prairie wetlands. Hydrobiologia 539: 171-188.

van der Valk AG, Davis CB. 1978. The role of seed banks in the vegetation dynamics of prairie glacial marshes. Ecology 59: 322-335.

Voldseth RA, Johnson WC, Gilmanov T, Guntenspergen GR, Millett BV. 2007. Model estimates of land-use effects on water levels of northern prairie wetlands. Ecological Applications 17: 527-540.

Voldseth RA, Johnson WC, Guntenspergen GR, Gilmanov T, Millett B. 2009. Adaptation of farming practices could buffer effects of climate change on northern prairie wetlands. Wetlands 29: 635-647.

Wagner G. 1997. Studies of the northern leopard frog (Rana pipiens) in Alberta. Alberta Environmental Protection, Wildlife Management Division, Wildlife Status Report no. 9.
Weller MW. 1988. Issues and approaches in assessing cumulative impacts on waterbird habitat in wetlands. Environmental Management 12: 695-701.

- 1994. Freshwater Marshes. 3rd ed. University of Minnesota Press.

1999. Wetland Birds. Habitat Resources and Conservation Implications. Cambridge University Press.

Weller MW, Fredrickson LH. 1974. Avian ecology of a managed glacial marsh. Living Bird 12: 269-291.

Weller MW, Spatcher CE. 1965. Role of Habitat in the Distribution and Abundance of Marsh Birds. Iowa State University Agricultural and Home Economics Experimental Station. Special Report no. 43.

Winter TC. 2000. The vulnerability of wetlands to climate change: A hydrologic landscape perspective. Journal of the American Water Resources Association 36: 305-311.

Winter TC, Rosenberry DO. 1995. The interaction of groundwater with prairie potholes in the Cottonwood Lake area, east-central North Dakota, 1979-1990. Journal of Hydrology 15: 193-221.

Winter TC, Woo MK. 1990. Hydrology of lakes and wetlands. Pages 159187 in Wolman MG, Riggs HC, eds. Surface Water Hydrology: The Geology of North America, vol. 1. Geological Society of America.

Wolfram S. 1999. The Mathematica Book. 4th ed. Cambridge University Press.

W. Carter Johnson (carter.johnson@sdstate.edu), Richard A.Voldseth, and Craig Olawsky are with the Department of Horticulture, Forestry, Landscape, and Parks, at South Dakota State University in Brookings. Brett Werner is with the Department of Environmental Studies at St. Olaf College, Northfield, Minnesota. Glenn R. Guntenspergen is with the US Geological Survey Biological Resources Division at Patuxent Wildlife Research Center in Laurel, Maryland. Bruce Millett is with the Department of Geography at South Dakota State University in Brookings. David E. Naugle is with the Wildlife Biology Program at the University of Montana, Missoula. Mirela Tulbure is with the GIS Center of Excellence at South Dakota State University in Brookings. Rosemary W. H. Carroll is with Desert Research Institute, University of Nevada, in Reno. John Tracy is with the Idaho Water Resources Research Center, at the University of Idaho in Boise.

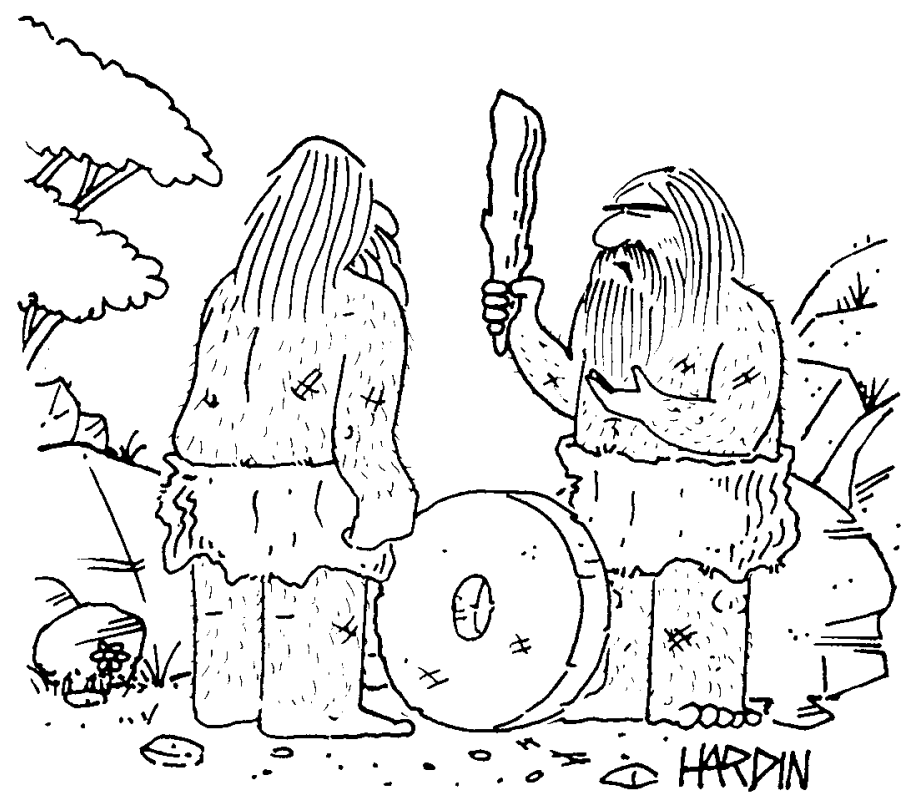

"The wheel Kept getting stolen-Until I
invented 'The club'," 